\title{
ЭКОЛОГИЧЕСКАЯ БЕЗОПАСНОСТЬ СЕЛЬСКОГО ХОЗЯЙСТВА И СЕЛЬСКОХОЗЯЙСТВЕННОЙ ПРОДУКЦИИ - РЕАЛЬНЫЕ ШАГИ
}

\section{ENVIRONMENTAL SAFETY OF AGRICULTURE AND AGRICULTURAL PRODUCTS ARE REAL STEPS}

\section{Barsukova \\ I. Glazunova \\ T. Korol \\ N. Lagutina}

Summary. The theory of environmental risk is the basis on which the entire construction of the concept of environmental safety is strung, and the definition of the level of acceptable risk is already an applied part of it.

Ensuring environmental safety is carried out through a certain system of measures, which is called the concept of sustainable development.

Today, the world is actively looking for ways to ensure the environmental safety of both agriculture and agricultural products.

The article presents the measures that are being implemented in our country, in this area, applying and processing the experience of advanced countries.

Keywords: ecological safety, ecological safety of agriculture, ecological safety of agricultural products, best available technologies, organic products.
Барсукова Мария Васильевна

Старший преподаватель, ФГБОУ ВО «Российский государственный аграрный университет - МСХА

им. К.А. Тимирязева» gribovaa@rambler.ru

Глазунова Ирина Викторовна К.т.н., дочент, ФГБОУ ВО «Российский государственный аграрный университет - МСХА им. К. А. Тимирязева»

ivglazunova@mail.ru

Король Татьяна Степановна

К.т.н., дочент, ФГБОУ ВО «Российский государственный аграрный университет - МСХА им. К. А. Тимирязева» tskorol@gmail.com Лагутина Наталия Владимировна К.т.н., дочент, ФГБОУ ВО «Российский государственный аграрный университет - МСХА им. К. А. Тимирязева» Oie@rgau-msha.ru

Аннотация. Теория экологического риска является той основой, на которую нанизывается вся конструкция концепции экологической безопасности, а уже определение уровня приемлемого риска является прикладной ее частью.

Обеспечению экологической безопасности, осуществляется за счет определенной системы мер, которая носит название концепция устойчивого развития. Экологическая безопасность, понятие многоплановое, в него включаются, как усилия по ликвидации в случае возникновения чрезвычайных ситуаций, так и определенные механизмы по управлению и регулированию, способные, не только прогнозировать, но и не допускать ЧС.

Сегодня в мире активно ищутся пути, способные обеспечить экологическую безопасность, как сельского хозяйства, так и сельскохозяйственной продукции.

В статье представлены те меры, которые реализуются в нашей стране, в рассматриваемой области, применяя и перерабатывая опыт передовых стран.

Ключевые слова: экологическая безопасность, экологическая безопасность сельского хозяйства, экологическая безопасность сельскохозяйственной продукции, наилучшие доступные технологии, органическая продукция. 
Э кологическую безопасность в соответствии с Указом Президента РФ от 31 декабря 2015 г. № 683 «О стратегии национальной безопасности Российской Федерации» отнесена к национальной безопасности Российской Федерации.

Термин «экологическая безопасность» на федеральном уровне закреплён в Федеральном законе от 10.012002 № 7-Ф3

В Ф3 - № 7 «Об охране окружающей среды», введено определение этого термина, которое фиксируется на жизненных интересах человека и природной среды от возможного негативного воздействия хозяйственной и иной деятельности, чрезвычайных ситуаций природного и техногенного характера, их последствий [10].

«Процессом обеспечения защищенности жизненно важных интересов личности, общества, природы и государства от реальных и потенциальных угроз, создаваемых, как естественным способом, так и техногенным воздействиями является экологическая безопасность» [1] — определение применяется в ходе заседаний Совета Безопасности Российской Федерации.

Фактически в данном определении представлен действенный механизм, в виде процесса обеспечения, позволяющий активно осваивать бюджетные средства и при этом ни за что не отвечать.

Вторая часть данного определения, так же отправляет нас к балансированию для поиска равновесия, то есть отсутствует хотя бы в принципе решение конкретных экологических проблем.

Большинство определений, данных в учебниках по экологии, являются перепелкой в той или иной мере выше приведенных определений.

Наиболее адекватное и системное определение экологическая безопасность представлено в монографии ряда ученых-экологов, под руководством В.И.Данилов-Данильян, в которой фиксируется внимание на способности государства не только устранять возникающие экологические опасности, но и контролировать, а также посредством научных методов прогнозировать их и фактически осуществлять обеспечения благосостояния общества и здоровья людей [2].

Здесь можно фактически прочувствовать тот результат, который от государства ожидает социум. Результат, может проявляться как в виде улучшении экологической обстановки, так и посредством понижения отрицательного воздействия негативных факторов.
Особенностью здесь является тот факт, что появляется возможность на конкретных цифрах, показать динамику процесса, как положительного, так и отрицательного. При этом, при положительной динамике, можно говорить о количественных характеристиках, которые показывают улучшении качества, прежде всего земельных, водных и лесных ресурсов и т.д.

При обнаружении отрицательной динамики, следует активнее проводить мониторинг, особенно в том случае, если анализируется системы экологической безопасности сельского хозяйства. Тем более, что она как за рубежом, так и в нашей стране базируется на его результатах, полученных за определенный период времени. Следует отметить, что на многих предприятиях агропромышленного комплекса принимаются меры, направленные на охрану окружающей среды [3].

В свою очередь, для того, чтобы преломить отрицательную динамику, одного мониторинга не достаточно. Положительный эффект в сельском хозяйстве может быть достигнут только от комплексного подхода, который на сегодня активно применяется в передовых зарубежных странах. Он включает в себя, налаживание эффективной системы управления всей структурой экологической безопасности сельского хозяйства. Сюда входит, прежде всего, как производство соответствующих технических средств, так и разработки новых экологически безопасных технологий. Кроме того, она включает элементы, жесткого контроля, который предназначен для слежения за качеством отбора и эффективности применяемых технологий и востребованных для их внедрения технических средств.

Улучшение экологической обстановки, которое наблюдается во многих старинах ЕС, связано с проводимой в этих сельскохозяйственной политики. Вопросам продовольственной и экологической безопасности, в зарубежных экономически развитых странах уделяется пристальное внимание уже достаточно давно, в результате была сформирована действенная система по использованию Best Available Techniques (BAT), что переводиться как наилучшие доступные технологии. В основу ее функционирования положены

экономически обоснованные затраты, направляемые на рациональное природопользование. При этом на регулярной основе формируются справочники ВАТ, получившие своё название Best Available Techniques REFerence Document (BREF), что переводиться как справочный документ по наилучшим доступным методам.

Данную методику планируется перевести на российскую почву и начать создавать подобные справочники наилучших доступных технологий (НДТ) [9]. 
В нашей стране, хоть и с существенным запаздыванием, но также активно взялись за обеспечение решение рассматриваемых вопросов и проблем [4].

В этой связи, в настоящий момент уже реализуется национальный проект «Экология», содержащего 11 федеральных проектов, в то числе и «Внедрение наилучших доступных технологий».

ГОСТ Р 54097-2010, дает четкое определение НДТ, в нем, в частности, рассматриваемые технологии представлены как технологический процесс и/или технический метод, основная задача которого за счет новейших достижений науки и техники снизить отрицательный эффект, получаемый о хозяйственной деятельности.

Область применения НДТ весьма разнообразна, и в распоряжении Правительства РФ от 24.12.2014 № 2674-р [8], представлен исчерпывающий список тех направлений, в которых могут быть применены новейшие технологии.

TK-113, так обозначается технический комитет в котором созданы рабочие органы и сформирована действенная структура, включающая в себя действенные технические рабочие группы, основной задачей которых является разработка по каждой конкретной отрасли соответственных информационно-технических справочников НДТ [7].

Условия ведения сельского хозяйства, климатические факторы и географические просторы российской территории, не только превосходит европейские страны, но и обладают разно векторными принципами его осуществления, при этом кардинально отличаясь в разных регионах страны. Эти положения должны постоянно учитываться при разработке справочников НДТ, при наполнения соответствующими сельскохозяйственными технологиями.

Механизм действия НДТ базируется на определенных принципах и требует пересмотра существующего подхода. Новый подход, в основе которого лежит НДТ, В качестве ключевого элемента своей деятельности определил мониторинг экологического состояния окружающей среды, который, проводиться в определенном цикле и улавливает положительные, либо отрицательные эффекты от применения соответствующих технологий.

Особенность методики НДТ заключена в получении сельскохозяйственной продукции, в первую очередь за счет синтеза, как средств, так и методов, её получения, при этом, она обладает заданными как качественными, так и с количественными характеристиками.
При этом, особенностью здесь является тот факт, что в данном случае при использовании технологий учитываются региональные особенности, это прежде всего природно-климатические его условия.

Таким образом, справочники НДТ, выполняют, в том числе и охранительную функцию, на их основе происходит выдача комплексных природоохранных разрешений.

Следует напомнить, что бюджет национального проекта «Экология» составляет около 4 трлн. рублей, эти финансовые вливания приведут к улучшению качества жизни людей по всей стране. И в качестве основного механизма выбрано внедрение НДТ, на них планируется выделить 2,5 трлн. рублей из внебюджетных источников и это станет ключевой составляющей проекта.

В настоящий момент уже создана нормативная база, способствующая переходу на НДТ. Таким образом, Правительством осуществлено регулирование на основе НДТ, и данное положение он образно назвал, новыми «правилами игры» [5].

Bce основные направления деятельности РСПП и ключевых министерств и ведомств работают в этом направлении.

В частности, в недрах Министерства сельского хозяйства Российской Федерации разработан законопроект об экологически чистой сельскохозяйственной продукции, сырье и продовольствии, он может вступить в силу с 1 января 2021 года.

Его создатели отмечают, что основная задача, заключается в решение таких проблем, как избавление от фальсификации экологически чистой продукции, с одной стороны, введение в заблуждение потребителей по поводу качества выпускаемой продукции, с другой и ряд подобных правовых коллизий.

С 1 января 2020 года вступил в силу, принятый еще в 2018 году Федеральный закон «Об органической продукции и о внесении изменений в отдельные законодательные акты Российской Федерации» от 03.08.2018 № 280-Ф3, в нем в частности определяется понятие органической сельскохозяйственной продукции. Инициатором данного законодательного акта также выступил Минсельхоз РФ.

Так, согласно документу, на сегодняшний день наиболее экологичным является органический способ производства. Его использование означает существенное уменьшение номенклатуры, как ветеринарных препа- 
ратов, так и удобрений, для их применения. Кроме того, имеет место также запрет на применение генетически модифицированных ингредиентов, предназначенных для улучшения почвы и средств защиты растений. Регламент предусматривает особые условия по размещению данного вида производство, как на значительном расстоянии, как от промышленных объектов, так и от иных источников загрязнения.

Если рассмотреть понятие «фермерской» и «эко» продукции то вышеприведенные требования не имеют к ним никакого отношения, так как данные виды продукции не закреплены в правовом поле.

АНО «Российская система качества» и/или Роскачество предусматривает разделить всю сельскохозяйственную продукцию на три основных вида, «зеленую», «экологическую» и «органическую» разработав на неё соответствующие стандарты [6].

Верхний уровень в иерархии займут органические продукты, в то время, как экологические продукты будут соответствовать одному либо нескольким критериям. К экологическим продуктам будут предъявляться менее строгие требования, по сравнению с органическими,

Особенностью, является, также и то, что не только само производство и хранение, но даже транспортировка данного вида продукции должны осуществляться отдельно.
Кроме того, имеется четкое ограничение по применению, технологий и методов генной инженерии и клонирования, использовании в производстве, либо хранении ионизирующего излучения, а также трансгенных организмов.

Существенным ограничениям подвергнется тара, как транспортная, так и потребительская, а также и упаковка, которые могут оказать негативное влияние на экологически чистую продукцию.

Проверка соответствия представленным нормативам будет осуществляться через единый государственный реестр, а производители, после внесения их продукции в реестр смогут размещать соответствующую маркировку на упаковке.

Таким образом, обеспечение качества продуктов питания, начинают играть ведущую роль при осуществлении комплексного подхода в обеспечении экологической безопасности в сельском хозяйстве.

В этой связи, сертификация готовой продукции сельского хозяйства, которая реализуется сегодня, практически ничего не дает, так как отсутствует сертификации удобрений и средств защиты растений. Отсутствуют сертификация применяемых почв и тех технологий, которые учитывают экологическое благополучие региона. Все это, на сегодняшний день не может гарантировать нм качество, ни безопасность продуктов питания.

\section{ЛИТЕРАТУРА}

1. Захаров, В. «Зеленая» экономика и модернизация. Эколого-экономические основы устойчивого развития / С. Бобылев //. На пути к устойчивому развитию России. - 2012. - №60.- С. 7-15.

2. Данилов-Данильян В.И., Залиханов М. Ч., Лосев К.С Экологическая безопасность. Общие принципы и российский аспект. М., 2001.

3. Фурман И.В., Барсукова М. В. Пути решения проблем охраны труда и экологии в организациях АПК //0храна и экономика труда. 2014 . № 3 (16). С. $72-77$.

4. Барсукова М.В., Лагутина Н. В. Сохранение биоразнообразия на Земле - необходимое условие выживания человека. // 0храна и экономика труда. 2017. № 1 (26). C. 19-22.

5. «Экология» вызвала резонанс. // http://ok51.ru/smi-centre/?page_id=1108\&print=13030

6. Поднять планку: в России появится стандарт экологической продукции. // https://radiosputnik.ria.ru/20190628/1556011088.html?in=t

7. Распоряжение Правительства РФ от 19 марта 2014 г. № 398-р и Постановление Правительства РФ от 23.12.2014 № 1458. // Информационно-правовая система КонсультантПлюс.

8. Распоряжению Правительства РФ от 24.12.2014 № 2674-р «0б утверждении Перечня областей применения наилучших доступных технологий». // Информационно-правовая система КонсультантПлюс

9. Integrated Pollution Prevention and Control (IPPC): Reference Document on Best Available Techniques for Intensive Rearing of Poultry and Pigs. July, 2003.

10. Федеральный закон от 10.012002 № 7-Ф3 «06 охране окружающей среды». // Информационно-правовая система КонсультантПлюс

○ Барсукова Мария Васильевна ( gribovaа@rambler.ru ), Глазунова Ирина Викторовна (ivglazunova@mail.ru ), Король Татьяна Степановна ( tskorol@gmail.com ), Лагутина Наталия Владимировна ( Oie@rgau-msha.ru ). Журнал «Современная наука: актуальные проблемы теории и практики» 